\title{
DISKURSUS BAHASA TUHAN DALAM PERSPEKTIF STRUKTURALISME LINGUISTIK MODERN
}

\author{
Oleh: \\ Tauhedi As'ad \& Munif Shaleh \\ Universitas Jember, Indonesia \\ Universitas Ibrahimy Situbondo, Indonesia \\ tauhediasad@gmail.com \& munifshaleh75@gmail.com
}

\begin{abstract}
:
God's language is not reached by human nature because God's language enters the parole area which cannot be verified, because parole language is God's revelation that cannot be intervened by the human language system. This model, is very new to be continued in the approach of Islamic studies, especially modern linguistic studies developed by Ferinand De Sausure, then by Paul Ricouer as the post structuralist father. However, if you re-understand the language of God in the perspective of modern linguistics as an approach in Islamic thought, then there is a problem that is addressed, namely the existence of God's Revelation which wraps into Arabic, then the corpus is formalized as a manuscript written by humans. Then God's revelation will lose the existence of authority as the owner of the message of revelation so that the Koran that is read now by all Muslims is no longer sacred and authentic. This is the revelation imprisoned by Arabic as the Ottoman Manuscripts.
\end{abstract}

Keyword: Strukturalisme, Linguistik Modern, Bahasa Tuhan

\section{A. Pendahuluan.}

Al-Quran sebagai kitab yang di amanatkan kepada Muhammad dengan bahasa lisan, kemudian disampaikan kepada umatnya dengan bahasa tulisan. Dengan proses perjalanan sejarah yang panjang, al-Quran tetap eksis sebagai bahan kajian oleh manusia sehingga al-Quran digunakan dengan beranekaragam pendekatan penafsiran untuk kepentingan konteks sosial yang melingkupinya. Salah satunya adalah alQuran dikaji dari sudut pandang kebahasaan yang sangat populer baik dari kalangan pemikir muslim klasik maupun pemikiran Islam kontemporer. Sedangkan pada abad kontemporer, para pemikir Islam banyak mengkaji teks al-Quran dengan menggunakan pendekatan linguistik modern, karenanya, bahasa adalah sebuah ekspresi dan tindakan untuk memaknai secara kontekstual sesuai dengan kebutuhan

$$
\begin{array}{l|l}
\text { JURNAL LISAN AL-HAL } & 367
\end{array}
$$


ruang dan waktu. Dengan demikian, konsep wahyu (al-Quran) sengaja untuk dibahasakan dalam bentuk bahasa Arab dan merupakan komunikasi antara eksistensi Tuhan dan manusia dengan parantara bahasa baik menggunakan bahasa lisan maupun bahasa tulisan.

Relasi antara Tuhan dengan manusia dalam bentuk komunikasi menggunakan bahasa sesuai dengan sistem bahasa masyarakat dimana bahasa hendak dibahasakan untuk diperuntukkan bagi penerimanya sehingga maksud al-Quran dapat dimengerti oleh masyarakat pemilik bahasa sebagai audien awal. Bahkan mayoritas umat Islam meyakini bahwa bahasa al-Quran adalah wahyu Tuhan secara sakral dan suci, bagi penulis al-Quran merupakan kitab mushaf yang ditulis oleh manusia untuk dijadikan pedoman dan petunjuk bagi alam semesta. Sementara didalam pemikiran studi Islam, pendekatan linguistik modern tersebut sangat diminati oleh pemikir Islam kontemporer misalnya; Hasan Hanafi, Fazlur Rahman, Nasr Hamid Abu Zaid, Farid Esack, Moh Arkoun, Moh Abid alJabiri dan Toshihiko Izutsu, untuk menjelaskan pesan dan makna al-Quran didalam perspektif linguistik modern sehingga pemaknaan bahasa alQuran tetap kontekstual.

Bagi kalangan pemikir Islam kritis, membuka peluang baru untuk memahami kembali bahasa Tuhan yang di firmankan dalam bentuk bahasa lisan kedalam bahasa tulisan sehingga al-Quran penuh pemaknaan yang kontekstual untuk keluar dari doktrinitas yang berkembang dikalangan pemikir Islam yang konservatif. Untuk menghindari dari bias ideologi tekstualitas al-Quran, maka perlu kiranya menggunakan pendekatan linguistik modern yang berkembang sesuai dengan konteks kekinian. Menurut Ibnu Khaldun, al-Quran diturunkan dalam bahasa orang-orang Arab dengan gaya yang menyentuh rasa bahasa masyarakat Arab. Masyarakat Arab seluruhnya memahami dan mengetahui makna alQuran, baik arti kata sinonim, kata tunggal maupun gramatikal bahasa.

\section{B. Kegelisahan Akademik}

Kegelisahan ini, berawal dari pandangan umum bahwa eksistensi al-Quran tidak perlu diperdebatkan, karenanya bahasa al-Quran dari Tuhan secara mutlak baik lafadz maupun maknanya sehingga makna pesan al-Quran menjadi sempit dan tunggal. Bagi penulis, al-Quran yang dipegang sekarang merupakan korpus resmi tertutup yang disepakati oleh politik penguasa untuk dijadikan pedoman oleh manusia yang ditulis berdasarkan dialektika antara pemilik bahasa dengan sistem makna. Akan tetapi, dari kalangan para pemikir Islam mengkaji teks al-Quran dari kata-

$368 \mid$ JURNAL LISAN AL-HAL 
kata kedalam bahasa terutama yang berhubungan dengan bahasa Tuhan perspektif linguistik modern, sehingga temuan makna kata-kata teks alQuran dapat dilacak dengan menggunakan sistem dan struktur kebahasaan ${ }^{1}$.

Sedangkan pendekatan yang digunakan disini, penulis menggunakan teori strukturalisme linguistik modern perspektif Ferdinand De Sausure yaitu linguistik yang terdiri dari Parole-langue, sinkronik-diakronik, penanda-petanda. Karenanya, teori tersebut sangat relevan untuk dikaji tentang kebahasaan dalam al-Quran guna menemukan maksud teks baik ungkapan secara individu (internal) maupun sistem sosial (eksternal). Didalam pandangan strukturalisme bahwa, teks yang berkaitan dengan struktur bahasa merupakan sistem masyarakat yang dimiliki oleh penutur bahasa yaitu masyarakat Arab. Sedangkan masyarakat Arab adalah masyarakat teks yang selalu mengacu pada teks lisan sehingga corak pemikiran Islam Arab bercorak literaltekstual atau al-Quran sebagai sentral teks dalam sejarah peradaban Arab sehingga peradaban Arab sebagai peradaban teks"2.

Sementara Hasan Hanafi mengemukakan bahwa, metode linguistik dapat mengukuhkan signifikansi linguistik sebagai pengantar untuk memahami wahyu karena wahyu bukanlah sejarah sakral, realitas unik, pribadi atau peristiwa tetapi adalah kalam yang tertulis, dibaca, didengar dan tersusun dari bahasa manusia tertentu yaitu bahasa Arab. Sebab wahyu adalah kalam yang mengandung makna yang dikandung oleh katakata. Disinilah tampak signifikansi kalam dan kata-kata didalam linguistik ${ }^{3}$. Al-Quran bukanlah wahyu melainkan bahasa teks yang tertulis dengan menunjukkan kata-kata dan susunan kalimat yang bisa dibahasakan oleh manusia dengan menggunakan linguistik sehingga manusia mampu menangkap makna teks al-Quran secara nalar-ilmiah.

Menurut penulis, yang harus dikritisi terhadap ontologi bahasa Tuhan adalah posisi Tuhan didalam menyampaikan pesan wahyu kedalam bentuk bahasa manusia sehingga eksistensi bahasa-pun juga berbeda, sementara manusia mempunyai eksistensi yang berbeda dengan Tuhan, berarti eksistensi keduanya berada ruang dan situasi yang berbeda, maka bahasa Arab sebagai media komunikasi antara bahasa Tuhan dengan bahasa manusia juga berbeda. Pertanyaannya adalah benarkah bahasa al-

1 Ahmad Zaki Mubarok, Pendekatan Strukturalisme Linguistik Dalam Tafsir alQuran Kontemporer, (Yogyakarta: elSAQ Press, 2007), 69.

${ }^{2}$ Nasr Hamid Abu Zaid, Tekstualitas al-Quran, Kritik Terhadap Ulumul Quran (Terj), (Yogyakarta: LKiS, 2001), 1.

${ }^{3}$ Hasan Hanafi, Hermeneutika al-Quran, (Terj), (Yogyakarta: Nawesea, 2009), 11. 
Quran berbahasa Arab adalah bahasa Tuhan? untuk mengetahui keotentisitas bahasa al-Quran sebagai bahasa Tuhan yang dianggap sakral dan suci dikalangan mayoritas umat Islam, maka bagi penulis, bahwa alQuran tidak lagi otentik sebagai bahasa Tuhan yang sakral, karenanya alQuran bercampur tangan dengan bahasa dialek yang beranegaragam. Kemudian penulis menjelaskan bahasa Tuhan baik konsep wahyu, alQuran dan Mushaf Usmani dengan pendekatan teori strukturalisme linguistik modern.

\section{Linguistik Modern Ferdinal De Saussure}

Sebagaimana dijelaskan diatas, bahwa pendekatan linguistik struktural sangat signifikan untuk cara mengalisa bahasa didalam struktur dan sistem kebahasaan yang dikembangkan oleh pemikiran strukturalisme maupun pemikir Islam dan atau menggunakan pendekatan linguistik modern didalam memahami bahasa al-Quran. Pada umumnya, unsur-unsur linguistik modern yang digunakan oleh para pengkaji kebahasaan diantaranya adalah konsep parole dan langue, sinkronik dan diakronik serta penanda dan petanda, sedangkan konsep tersebut masuk kepada wilayah semiologi (ilmu tanda). Oleh karenanya, penulis akan merinci dan menjelaskan konsep lingustik secara garis besarnya untuk mempermudah pengertian yang dikembangkan oleh pemikir linguistik modern yang dipelopori oleh tokoh strukturalisme yaitu Ferdinand De Sausure.

\section{Parole dan Langue.}

Didalam strukturalisme linguistik modern, bahwa bahasa terbagi dua bagian yaitu parole dan langue ${ }^{4}$. Sedangkan pertama, parole adalah merupakan perwujudan individual dari sistem bahasa atau langue, yaitu tindak bicara konkret seorang individu yang pada saat tertentu dengan menggunakan sistem tanda atau langue tertentu untuk menyampaikan pikiran pesannya kepada orang lain yang terlibat dalam komunikasi dan masyarakat hidup dalam satu tingkat keberadaan yang sama. Kedua, langue adalah sistem bahasa yang lahir dari interaksi unsur-unsur yang terdapat dalam masyarakat yang bertutur, kemudian menjadi milik bersama dari masyarakat tersebut. Sementara suatu tuturan yang bersifat personal dan individu yang digunakan seseorang dalam komunikasi dengan merujuk pada sistem bahasa tertentu.

4 Sri Ahimsa Putra, Strukturalisme Levi Strauss: Mitos Dan Karya Sastra, (Yogyakarta: Galang Press, 2001), 81.

370 JURNAL LISAN AL-HAL 
Perbedaan antara parole dan langue didalam linguistik, yaitu terletak pada bahasa muncul secara pribadi dan individual, kemudian direkam kedalam sistem bahasa yang dikonstruksi oleh sosial. Jadi parole mengkonkretkan wujud makna bahasa secara individu, sementara langue lebih mengarah pada sistem sosial yang dipengaruhi oleh pemilik penutur bahasa masyarakat didalam situasi yang sama. Menurut Sausure, langue bukanlah penutur, akan tetapi langue merupakan produk yang direkam individu secara pasif. Sebaliknya, parole adalah suatu tindakan individual dari kemauan dan kecerdasannya ${ }^{5}$. Oleh karenanya, langue merupakan kehadiran suatu hasil sebagai kontrak masa lalu dengan para anggota masyarakat.

Intinya, para pemikir linguistik modern membatasi pada pembahasan tentang langue, karena langue merupakan sistem masyarakat sosial sesuai dengan sistem bahasa sebagai fakta. Dengan kata lain, konsep langue masuk pada kategori ilmiah yang bisa diteliti didalam lingustik. Sedangkan konsep parole merupakan pembahasan non ilmiah, karena bersifat personal yang tidak bisa dilacak didalam linguistik. Menurut Sausure, langue adalah produk sosial dari kemampuan bahasa dan sekaligus merupakan keseluruhan hubungan yang dipengaruhi oleh kelompok sosial untuk memungkinkannya menggunakan kemampuan. Sementara, parole adalah jumlah dari apa yang dituturkan orang yang mengandung hubungan individual dan tindakan pembunyian bagi pengungkapan hubungan tersebut sehingga parole tidak bersifat kolektif6.

\section{Sinkronik Dan Diakronik.}

Linguistik modern mempunyai dua terma yaitu bisa didekati secara sinkronik dan diakronik. Sedangkan Sinkronik adalah bersifat ahistoris yang lepas dari tujuan historis. Sementara Diakronik adalah didekati secara historis terhadap linguistik, sebagaimana yang dilakukan oleh penggagas pendahulunya. Menurut Saussure, linguistik harus memperhatikan sinkronik sebelum menghiraukan diakronik. kemudian etimologi keduanya berasal dari kata yunani khronos (waktu) dan dua awalan syn- dan dia- masing-masing berarti "bersamaan" dan "melalui"7. Maka dari itu, sinkronik dapat di jelaskan sebagai "bertepatan waktu" dan diakronik sebagai "menelusuri waktu". Sinkronik menunjukkan

${ }^{5}$ Kurniawan, Semiologi Roland Barthes, (Magelang: Indonesiatera, 2001), 27.

${ }^{6}$ Kurniawan, Semiologi Roland Barthes....... 28.

7 K. Bartens, Fisafat Barat Kontemporer Prancis (Terj), (Jakarta: Gramedia Pustaka Utama, 2001), 184. 
pandangan yang sama sekali lepas dari tinjauan historis, sedangkan diakronik adalah peninjauan historis. Sementara antara sinkronik dan diakronik masih ada perbedaan didalam mengunakan linguistik untuk menempatkan pada posisi parole dan langue.

Jadi pandangan struktrulisme yang digagas oleh Ferdinand De Saussure fokus kepada konsep sinkronik, karena sinkronik tidak perlu menelusuri waktu terhadap bahasa sehingga sistem bahasa harus ada pemutusan epistemologi diakronik. Hubungan sinkronik dan diakronik dapat dibandingkan dengan pemotongan sebuah penampang batang pohon $^{8}$. Analogi sinkronik, jika memotong batang secara melintang akan temukan penampang dengan gambar yang kurang lebih rumit yang menunjukkan pengelompokkan dengan pengaturan tertentu. Sedangkan gambaran diakronik, jika memotong batang secara memanjang dan menemukan penampang yang menunjukkan serat-serat membentuk tumbuhan.

Sedangkan pengertian sinkronik adalah kajian yang tidak melibatkan historisitas obyek dengan memandangnya pada penggal waktu tertentu, dan keadaan stabil. Model ini menjadi kecenderungan kaum strukturalis didalam melakukan analisis terhadap bahasa. Sementara diakronik adalah kajian yang memandang perkembangan obyeknya sepanjang masa dan bersifat historis. Menurut Kridalaksana, kajian bahasa semacam ini bersifat tidak ilmiah ${ }^{9}$. Dengan memperioritaskan uraian sinkronik, tidak berarti Sausure menolak sama sekali penyelidikan diakronik. Linguistik historis komparatif membandingkan bahasa sebagai sistem-sistem. Oleh karena itu, sistem harus dilukiskan terlebih dahulu berdasarkan prinsip-prinsip sinkronik.

\section{Penanda dan Petanda}

Pemikiran Sausure yang paling penting dalam semiologi adalah pandangan tentang tanda sebagai media komunikasi. Tanda membagi dua kategori yaitu penanda dan petanda. Sedangkan, penanda adalah bunyi yang bermakna atau tulisan yang bermakna didalam aspek material, yaitu apa yang dikatakan dan di tulis atau dibaca. Sementara, petanda adalah merupakan gambaran mental, yakni pikiran atau konsep dari bahasa ${ }^{10}$.

${ }^{8}$ Kurniawan, Semiologi Roland Barthes........ 30.

9 Ahmad Zaki Mubarok, Pendekatan Strukturalisme Linguistik Dalam Tafsir alQuran Kontemporer, (Yogyakarta: elSAQ Press, 2007), 81.

10 K. Bartens, Fisafat Barat Kontemporer Prancis (Terj), (Jakarta: Gramedia Pustaka Utama, 2001), 80.

372 JURNAL LISAN AL-HAL 
Jadi yang harus diperhatikan adalah bahwa dalam tanda bahasa yang konkret kedua unsur tidak bisa dilepaskan. Tanda bahasa selalu mempunyai dua segi yaitu penanda dan petanda, suatu penanda tanpa petanda tidak berarti apa-apa. Sebaliknya, suatu petanda tidak mungkin disampaikan atau ditangkap lepas dari penanda yang ditandakan tersebut, termasuk tanda itu sendiri, dengan demikian merupakan suatu faktor linguistik.

Jika sistem bahasa yang dipahami oleh pembaca atau subyek yang terlibat dalam suatu tindak komunikasi. Ada dua syarat yang harus dipenuhi ${ }^{11}$. Pertama, keberadaaan yang sama dengan subyek dalam tindak komunikasi budaya yang sama, misalnya, antara Y dan X harus sama-sama menggunakan satu sistem budaya. Jika salah satu keduanya berasal sistem budaya lain, maka keduanya berarti hidup dalam eksistensi yang berbeda. Kedua, penggunaan sistem bahasa yang sama dalam sistem budaya yang sama, maka keduanya juga mengikuti bahasa budaya yang sama pula. Artinya, Y dan X, disamping berada dalam eksistensi sistem budaya yang sama, juga diharuskan menggunakan sistem bahasa budaya yang sama.

\section{Strukturalisme Cara Analisis Bahasa Tuhan}

\section{Parole Tuhan: Konsep Wahyu}

Memasuki analisis struktur dan sistem bahasa dalam linguistik modern untuk mengkaji tentang konsep parole Tuhan yang disebut dengan wahyu. Sepintas lalu, untuk memahami konsep wahyu secara umum adalah pesan yang disampaikan kepada Muhammad sebagai penerima awal. Tujuan untuk menemukan keberadaan wahyu Tuhan dengan menggunakan linguistik struktural tersebut lebih cocok menggunakan kata "pesan". Pesan Tuhan tidak dibisa dikaji secara langue atau sistem bahasa, karena eksistensi Tuhan berada posisi supra-natural yang non ilmiah sehingga pesan Tuhan tidak terikat ruang dan waktu, berarti secara linguistik, bahasa Tuhan masuk pada wilayah parole. Berbeda dengan manusia, manusia adalah makhluk natural yang terikat pada ruang dan waktu, berarti secara linguistik, bahasa manusia masuk pada kategori langue.

Sedangkan bentuk penyampaian pesan Tuhan kepada Muhammad secara linguistik berjalan melalui dua arah, Tuhan berposisi sebagai pihak yang aktif menyampaikan, dan Muhammad berposisi sebagai pihak penerima awal. Jika di lihat dari sisi semantik, proses penyampaian pesan

11 Toshihiko Izutsu. Relasi Tuhan Dan Manusia; Pendekatan Semantik Terhadap alQuran, (Terj), (Yogyakarta: Tiara Wacana, 1997), 171-193. 
dari Tuhan kepada Muhammad mengalami masalah, sebab keduanya berada dalam taraf eksistensi yang berbeda. Tuhan berada taraf eksistensi supra-natural, pada saat yang sama Muhammad berada dalam taraf eksistensi natural sebagai manusia biasa. Kemudian, problem eksistensi keduanya juga berimplikasi pada sistem bahasa yang digunakan. Sedangkan Tuhan sebagai supra-natural menggunakan bahasa non ilmiah, sementara Muhammad sebagai makhluk natural menggunakan sistem bahasa ilmiah.

Walaupun demikian, problem tersebut bisa diatasi sehingga komunikasi keduanya bisa berjalan lancar. Kelancaran komunikasi itu ditempuh melalui penyamaan sisi eksistensialnya ${ }^{12}$. Proses penyamaan itu mengambil dua bentuk, pertama peleburan Muhammad ke dalam dimensi dua kemalaikatan, karena manusia mempunyai potensi memasuki dunia kemalaikatan sehingga dia mampu memahami dan berkomunikasi dengan sistem bahasa komunikasi Tuhan. Kedua, Tuhan masuk ke dalam dimensi dunia kemanusiaan, sehingga Tuhan melakukan komunikasi dengan sistem bahasa manusia. Dengan kata lain, keduanya bertemu pada titik, dimana Tuhan masuk kedalam alam natural dan Muhammad meninggalkan alam natural menuju alam non natural.

Menurut Ibnu Khaldun, jiwa manusia terbagi tiga golongan. Pertama jiwa yang tidak sanggup secara qodrati untuk mencapai pada pemahaman kerohanian melainkan hanya sampai pada pemahaman yang bersandar kepada indera dan khayal, mereka berasal dari masyarakat awam. Kedua golongan murni yang menggunakan pemikiran tanpa menyandarkan dirinya pada aspek inderawi atau fisik, mereka adalah para wali dan ulama. Ketiga golongan yang secara qudrati yang mempunyai sifat yang tidak saja seperti dua sifat sebelumnya, tetapi dia mempunyai sifat yang dapat meningkat dan menuju kedunia malaikat. Mereka pada umumnya adalah para Nabi dan utusan. Karena itu, suatu saat dia bakal meninggalkan dunia hayat dan menuju dunia malaikat atau alam yang tidak nyata ${ }^{13}$.

Disamping penyamaan dari aspek eksistensialnya, proses itu juga menampilkan penyamaan pada aspek bahasa yang digunakan keduanya. Sebagai pemilik pesan, Tuhan berkomunikasi dengan Muhammad, tentunya menggunakan bahasa yang dapat dimengerti dan dipahami oleh dirinya dengan Muhammad sebagai lawan komunikasinya. Menurut

12 Aksin Wijaya, Arah Baru Studi Ulum al-Quran; Memburu Pesan Tuhan Di Balik Fenomena Budaya, (Yogyakarta: Pustaka Pelajar, 2009), 74.

13 Ibnu Khaldun. Muqaddimah, (Terj), (Jakarta: Pustaka Firdaus, 1986), 118.

$374 \mid$ JURNAL LISAN AL-HAL 
Sausurean, sistem bahasa yang digunakan dalam dua orang tanpa melibatkan peran masyarakat banyak, biasanya menggunakan bahasa dalam bentuk parole. Proses peleburan bahasa keduanya dalam bentuk parole merupakan pilihan-pilihan komunikasi bebas yang digunakan antara Tuhan dengan Muhammad dan serta lepas dari aturan apapun. Tuhan menggunakan bahasa dalam bentuk parole, untuk menyesuaikan diri dengan Muhammad yang bertugas sebagai penerima parole Tuhan sesuai dengan apa yang dimaksudkan Tuhan atau memang bahasa itu sama-sama dikenal keduanya.

Komunikasi itu mengalami dua bentuk ${ }^{14}$, pertama, media yang digunakan berbentuk isyarat atau ilham, dimana dengan isyarat itu Muhammad dapat memahaminya. Bentuk ini terutama terjadi pada saat Muhammad melakukan peleburan kedalam eksistensi alam non natural. Pada saat itu, tentu Muhammad mampu berkomunikasi dengan bahasa Tuhan yang supra-natural, karena secara eksistensial Muhammad telah masuk ke dalam dunia ketuhanan. Jadi bahasa yang digunakan keduanya dalam tindak komunikasi adalah posisi langue menjadi parole. Bentuk kedua, menggunakan sistem bahasa verbal, karena Tuhan masuk ke dalam dunia manusia sehingga Tuhan dapat menyesuaikan diri dengan bahasa manusia. berarti tindak komunikasi keduanya adalah dari parole menjadi langue.

Terlepas dari perbedaan ini, didalam bentuk penyampaian wahyu Tuhan kepada Muhammad dengan eksistensi sistem bahasa yang berbeda baik secara verbal maupun isyarah. Jika sistem bahasa yang digunakan Muhammad adalah bahasa wahyu berarti posisinya berada pada parole Tuhan yang non ilmiah. Menurut pandangan Sausurean, bahwa analisis bahasa yang digunakan hanya berada pada sistem masyarakat yang sama yaitu langue. Berbeda dengan parole, Parole Tuhan berada diluar wilayah analisis bahasa. Karena itu, penulis meyakini bahwa wahyu Tuhan tidak otentik dan sakral didalam memahami secara linguistik struktural, maka yang hendak dikritisi adalah wahyu Tuhan dalam membahasakan kedalam sistem bahasa yang dimiliki oleh pemilik bahasa yaitu masyarakat Arab.

Salah satu model dan bentuk pewahyuan secara parole yang digunakan dalam bentuk komunikasi antara Tuhan dan Manusia dengan sistem bahasa sebagai media komunikasi, ada tiga unsur yang terkait dengan konteks wahyu, yang pertama komunikasi. Dalam bingkai teori komunikasi, Tuhan berposisi sebagai komunikator aktif, sedangkan

14 Aksin Wijaya, Arah Baru Studi Ulum al-Quran; Memburu Pesan Tuhan Di Balik Fenomena Budaya, (Yogyakarta: Pustaka Pelajar, 2009), 77. 
Muhammad berposisi sebagai komunikan pasif, dan bahasa Arab adalah sebagai media komunikasi. Ini mengandaikan dalam komunikasi tidak terdapat lebih satu orang, minimal dua orang. kedua tidak harus bersifat verbal. Dengan kata lain, isyarat yang digunakan dalam komunikasi tidak selalu bersifat linguistik. Ketiga selalu terdapat hal-hal yang bersifat misterius, rahasia dan pribadi ${ }^{15}$. Didalam pandangan al-Quran, wahyu yang diturunkan pada manusia ada tiga bentuk, kemudian dianalisis secara linguistik.

Pertama, wahyu (ilham) adalah terjadinya (jatuhnya) makna pada orang yang menjadi sasaran pemberian wahyu tanpa melalui lafadz yang diciptakannya, akan tetapi melalui penyingkapan makna itu kepada orang tersebut dengan perantara suatu perbuatan yang dilakukan dalam diri seorang untuk diajak bicara, sebagaimana firman Tuhan; "maka jadilah dia dekat (pada Muhammad) dua ujung busur panah atau lebih dekat lagi. Lalu dia menyampaikan kepada Muhammad apa yang telah Tuhan wahyukan" (QS. An-Najm: 9-10). Dengan analisis linguistk, bentuk komunikasi yang diperbuat oleh seseorang didalam menerima pesan makna tanpa lafadz, merupakan parole Tuhan yang non natural, sehingga bahasa yang digunakan memakai tanda-tanda isyarah atau ilham.

Kedua, wahyu yang hadir dari belakang hijab. Wahyu dalam bentuk ini adalah pembicaraan yang diperbuat melalui sarana lafadz yang diciptakannya didalam diri seorang yang menjadi pilihannya untuk diajak bicara. Sebagaimana peristiwa Musa yang telah disebutkan didalam alQuran; "dan Tuhan berbicara kepada Musa dengan suatu pembicaraan" (QS. An-Nisa': 164). Ayat ini mengacu pada linguistik yang bernuansa parole secara personal serta tindak komunikasi antara keduanya mengandung rahasia atau dibelakang tabir. Dalam pandangan linguistik, bahwa tetap tidak masuk pada wilayah ilmiah, karena proses komunikasi didalam menerima pesan wahyu bersifat supra-natural.

Ketiga, kalam Tuhan yang berbunyi atau "Dia mengutus seorang utusan", merupakan bentuk wahyu bagian ketiga. Wahyu dalam bentuk seperti ini, disampaikan melalui perantara malaikat Jibril. Terkadang Jibril menyampaikan pesan wahyu kepada Muhammad melalui alam ghaib dengan cara Muhammad memasuki alam kemalaikatan dan terkadang Jibril mengubah diri menjadi bentuk manusia16. Banyak contoh yang berkaitan dengan model ketiga tersebut, misalnya ketika Muhammad

15 Aksin Wijaya, Arah Baru Studi Ulum al-Quran; Memburu Pesan Tuhan Di Balik Fenomena Budaya, (Yogyakarta: Pustaka Pelajar, 2009), 54-55.

16 Ibnu Khaldun. Muqaddimah, (Terj), (Jakarta: Pustaka Firdaus, 1986), 107-121.

376 JURNAL LISAN AL-HAL 
menerima perintah pertama di Gua Hira', dimana dia berdialog dengan sosok makhluk yang diyakini sebagai utusan Tuhan, dan Muhammad didatangi sosok berbaju putih, ketika sedang berdakwah bersama para sahabatnya, kemudian bertanya kepada Muhammad tentang Islam, Iman dan Ihsan. Berdasarkan fakta tersebut, bentuk komunikasi yang digunakan masih pada wilayah parole atau non ilmiah.

\section{Langue Arab: Konsep Al-Quran}

Pasca wahyu dalam bentuk parole Tuhan telah usai, maka selanjutnya, memahami kembali bahasa al-Quran untuk disampaikan kepada umatnya. Menurut Farid Esack, al-Quran merupakan teks tertulis (al-kitab) yang berfungsi sebagai teks tulisan mushaf ${ }^{17}$. Muhammad sebagai seorang utusan untuk disampaikan kepada masyarakat Arab sebagai audien awal sehingga proses penyampaian pesan wahyu harus di berlakukan pada posisi situasi yang sama. Sedangkan al-Quran berbahasa Arab, berarti sistem bahasa Arab harus berlaku sesuai dengan sistem masyarakat, dimana bahasa hendak disampaikan. Proses bentuk penyampaian wahyu yang berasal dari bahasa non ilmiah untuk di ajak berbicara terhadap masyarakat sebagai pemilik bahasa sehingga proses komunikasi efektif lancar dan saling memahaminya.

Namun proses ini tidak menimbulkan masalah, sebab dari sisi eksistensi, Muhammad berada dalam taraf yang sama dengan masyarakat Arab. Oleh karena itu, hidup dalam realitas budaya yang sama dan tentunya komunikasi antara Muhammad dengan masyarakat Arab menggunakan sistem bahasa yang sama, sehingga komunikasi antara Muhammad dengan masyarakat Arab berjalan lancar dan komunikatif. Akan tetapi, didalam konteks membahasan pesan wahyu sebagai bahasa non ilmiah kepada manusia yang menggunakan bahasa natural dan ilmiah, dari sisi sistem bahasa komunikasi menyisakan problem. Bahasa non ilmiah merupakan bahasa Tuhan yang tidak bisa di ilmiahkan, karena sistem bahasa Tuhan hanya dimiliki sebagai pemilik wahyu atau parole Tuhan semata.

Perbedaan inilah yang harus dirumuskan kembali kedalam kalam Tuhan yang bentuk sistem bahasa didalam linguistik sehingga tidak ada penyamaan eksistensi didalam menggunakan sistem bahasa yang berbeda dengan bahasa masyarakat. Sedangkan al-Quran sebagai bahasa Arab, maka sistem yang berlaku harus sesuai dengan sistem masyarakat, apa

17 Farid Esack, Samudera al-Quran (Terj), (Yogyakarta: Diva Press, 2007). 11. 
yang dikatakan oleh Paul Ricoeur sebagai dialektika subyektif-obyektif ${ }^{18}$. Dikatakan subyektif, Muhammad membahasakan pesan wahyu dengan menggunakan bahasa Arab untuk disampaikan kepada masyarakat Arab didalam situasi yang sama, sedangkan obyektif, bahasa Arab sebagai media komunikasi yang disampaikan kepada manusia secara obyektif dalam bentuk taraf eksistensi yang sama sehingga sistem bahasa al-Quran dapat dipahami oleh masyarakat yang bersangkutan.

Menurut Hasan Hanafi, bahasa yang dikatakan oleh Muhammad, ketika di wahyukan oleh Tuhan melalui perantara (Jibril) dan Muhammad langsung mendiktikannya kepada para penulis wahyu Hanafi Hasan ${ }^{19}$. AlQuran merupakan manifestasi dari wahyu yang disimpan kedalam pikiran Muhammad, kemudian para audien awal untuk menuliskannya. Agar pesan dapat dipahami oleh pihak penerima, dipersyaratkan penyampaian wahyu kepada manusia dengan menggunakan sistem bahasa yang sesuai dengan sistem bahasa masyarakat Arab sebagai audien awal wahyu. Jika tidak, pesan itu tidak akan dipahami dan tidak akan diterima oleh masyarakat yang menjadi sasaran pesan. Kenyataannya, problem bahasa itu dapat ditangani oleh Muhammad dan pesan tersebut dibahasakan dengan sistem bahasa yang digunakan masyarakat Arab yaitu bahasa $\operatorname{Arab}^{20}$.

Berdasarkan analisis ini, dapat dipahami bahwa bahasa Arab dijadikan bahasa wahyu, disebabkan oleh kenyataan bahwa dalam membahasakan wahyu Tuhan pada manusia diperlukan sebuah media atau sistem bahasa yang dapat dipahami oleh masing-masing subyek terlibat dalam komunikasi, terutama subyek yang menjadi sasaran pesan. Sebuah pernyataan bahwa Tuhan mengutus seorang Rasul dengan menggunakan bahasa kaumnya secara lnguistik adalah dalam pengertian diatas, bukan berarti sejak lawh al-Mahfuzh bahasa wahyu tertulis dengan bahasa Arab. Karena itulah, maka kalimat "lisanin Arabiyyin Mubin" menurut penulis adalah dalam pengertian sistem kebahasaan dialam natural manusia.

Jika pada tahap komunikasi Tuhan dengan Muhammad sebagai bentuk "transisi peralihan" dari parole Tuhan kepada langue (sistem bahasa masyarakat) Arab. Maka komunikasi antara Muhammad dengan

18 Paul Ricoeur, Filsafat Wacana; Membelah Makna Dalam Anatomi Bahasa, (Terj), (Yogyakarta: IRCiSoD, 2002). 51.

${ }^{19}$ Hasan Hanafi, Hermeneutika al-Quran, (Terj), (Yogyakarta: Nawesea, 2009), 41.

${ }_{20}$ Aksin Wijaya, Arah Baru Studi Ulum al-Quran; Memburu Pesan Tuhan Di Balik Fenomena Budaya, (Yogyakarta: Pustaka Pelajar, 2009), 51.

378 JURNAL LISAN AL-HAL 
masyarakat Arab semakin memastikan, bahwa peralihan dari parole Tuhan ke langue (sistem bahasa) masyarakat penerima wahyu pertama kali, merupakan "suatu keniscayaan". Tanpa peralihan tersebut, mustahil wahyu yang berisi pesan Tuhan yang bentuk bahasa parole Tuhan bakal diterima oleh manusia sebagai makhluknya ${ }^{21}$. Disinilah tampak, wahyu berkenalan dengan sistem bahasa natural, bahasa manusia, khususnya sistem bahasa masyarakat Arab.

Penyampaian pesan Tuhan dengan menggunakan bahasa Arab, tentunya masih menggunakan ungkapan bahasa lisan. Muhammad sebagai komunikator menyampaikan pesan Tuhan itu melalui bahasa lisan. Setiap kali menerima pesan, Muhammad menyampaikan kepada para sahabatnya, dan meminta untuk menghafalkannya. Tradisi mulia di masyarakat Arab misalnya; ditunjukkan dengan kebiasaan membaca syi'ir. Sedangkan tradisi menghafal ditunjukkan oleh banyaknya para penghafal wahyu dan hadits. Jika mengacu pada wahyu yang pertama yang disampaikan Tuhan kepada Muhammad sebagaimana uraian diatas sangat jelas menjadi buku bahasa lisan wahyu.

Singkatnya, perdebatan tentang apakah lafadz dan maknanya wahyu berasal dari Tuhan atau Muhammad yang menunjukkan pada realitas supra-natural dalam parole Tuhan atau di lawh mahfudz merupakan perdebatan yang tidak pada tempatnya, sebab wilayah supranatural itu berada di luar jangkauan kapasitas akal manusia. Perbedangan pandangan didalam ontologi kalam Tuhan yang telah diperdebatkan oleh manusia sepanjang sejarah sehinga fungsi teks al-Quran sebagai langue beralih pada posisi parole. Sehingga semua kalangan umat Islam meletakkan al-Quran pada posisi parole. Mestinya, perdebatan itu diharapkan pada wahyu yang kini telah dibahasakan dengan bahasa masyarakat Arab, sebab pada aspek inilah, wahyu mengalami naturalisasi yang kemudian lazim disebut al-Quran.

\section{Korpus Resmi Tertutup: Mushaf Usmani}

Komunikasi bahasa Arab yang digunakan adalah bahasa lisan dari wahyu Tuhan terjadi pada masa Muhammad masih hidup. Setelah Muhammad meninggal, maka pengganti perjuangan Islam diteruskan oleh para sahabat-sahabatnya yaitu Abu Bakar, Umar Bin khattab, Usman Bin Affan dan Ali Bin Thalib. Pasca meninggalnya Muhammad para sahabat sebagai khalifah telah berhasil mendakwahkan dan menyebarkan Islam

21 Aksin Wijaya, Arah Baru Studi Ulum al-Quran; Memburu Pesan Tuhan Di Balik Fenomena Budaya, (Yogyakarta: Pustaka Pelajar, 2009), 52. 
keluar semanjung Arab. Dicatat dalam sejarah bahwa perjuangan para empat khalifah mempunyai karakter dan corak tersendiri didalam memegang pemerintahannya sehingga perjalanan pemerintahannya tersebut, juga mengalami hambatan yang sangat signifikan dengan menggunakan beberapa cara yang digunakannya.

Dalam penyebaran Islam itu ada dual hal yang muncul yaitu dengan terpaksa, para sahabat menggunakan kekerasan dalam bentuk peperangan, dan munculnya perdebatan dikalangan para sahabatan tentang variasi bacaan al-Quran yang oleh Muhammad dibahasakan dengan tujuh huruf demi memudahkan para kabilah dengan menggunakan bahasa yang berbeda dalam membaca dan memahami al-Quran. Untuk mengantisipasi memudahnya eksistensi "keotentikan" al-Quran yang masih tersimpan didalam hafalan para sahabat demi menghindari konflik di antara umat Islam yang disebabkan variasi bacaan teks, maka diadakanlah pengumpulan ayat-ayat al-Quran yang pada mulanya masih berada di tangan para penghafal, dengan menyatukan bahasa. Dengan sangat cerdas, para sahabat menanggapi situasi tersebut, dan selesai secara sempurna pada masa pemerintahannya Utsman. Khalifah Utsman, kemudian membentuk tim penulis yang harus membukukan al-Quran, yang awalnya masih bertebaran di benak para penghafal dari yang terdapat di palapah kurma, batu serta kulit binatang kedalam sebuah Mushaf, yang kelak dinamakan dengan Mushaf Utsmani.

Pada tahap selanjutnya, peralihan dari bahasa parole Tuhan sebagai wahyunya dengan menggunakan bahasa individual menuju ke langue sebagai pemilik bahasa Arab yang disebut al-Quran dengan menggunakan bahasa lisan, kemudian bahasa al-Quran disebar-luaskan kedalam bentuk bahasa tulisan, maka inilah yang disebut dengan Mushaf Utsmani. Pada perjalanan naturalisasi wahyu Tuhan, yakni proses pembukuan dari bahasa lisan wahyu yang disebut al-Quran, kedalam bentuk, mushaf Utsmani yang ada ditangan umat Islam. Mushaf Utsmani ini dibaca, dihormati, sebagaimana layaknya membaca dan menghormati wahyu Tuhan yang sakral dan masih berbentuk bahasa lisan atau alQuran. Dengan posisi peralihan dalam bentuk lisan (wahyu) ke bahasa tulisan (mushaf). Menurut Moh Arkoun, mengemukakan anggapan yang memandang tiga unsur penting: pertama, ia menghubungkan proses pembakuan dan penutupan dalam penafsiran al-Quran dengan pengalihan dari bentuk lisan ke bentuk tertulis. Kedua, ia beranggapan bahwa dalam pemikiran manusia sering terjadi peralihan antara dua cara pemakaian 
bahasa. Ketiga, ia berpendapat bahwa bahasa lisan adalah bentuk bahasa yang lebih awal dari bahasa tulis (Ruslani, 2000:103-104).

Hubungan bahasa al-Quran dan Mushaf Ustmani, dengan pesan Tuhan terperangkap kedalam budaya masyarakat Arab, sebagai konsekuensi peralihan pesan Tuhan dari parole ke sistem bahasa Arab, maka dibawah ini akan dianalisis secara singkat bagaimana pesan Tuhan itu kian tak berdaya terperangkap dalam bahasa tulisan. Kemudian, dilanjutkan pada pelacakan perubahan aspek semantik wahyu dari peralihan bahasa lisan kedalam bentuk tulisan. Dan disamping peralihan dari parole Tuhan pada sistem bahasa atau langue masyarakat Arab, juga mengakibatkan terjebaknya pesan Tuhan adalah peralihan dari sistem bahasa Arab yang berbentuk lisan kepada bentuk tulisan dan perampingan satu bahasa, sedangkan bahasa Arab Quraisy yang menjadi Mushaf resmi umat Islam.

Bacaan teks al-Quran (Mushaf) telah ditetapkan dengan dialek Quraisy. Hal ini mendorong kita untuk berhepotesa, bahwa pembelaan asy-Syafie terhadap kemurnian al-Quran dari kata serapan non Arab, bukan hanya pembelaan terhadap bahasa Arab secara keseluruhan, melainkan juga terhadap kemurnian bahasa Quraisy dan penegasan atas dialek-dialek Arab lainnya. (Abu Zaid Naser Hamid, 1997:15). Dan pandangan Ibnu al-Jauzi bahwa al-Quran (mushaf) diturunkan dalam tujuh bahasa. Sebagian kalangan berpendapat; ia (tujuh bahasa bangsa Arab yang terpencar didalam al-Quran al-Karim dan masing-masing adalah milik kabilah yang termasyhur. Sementara ada kalangan lagi yang mengatakan adalah bahasa Quraisy, bahasa Yaman, bahasa Tamim, bahasa Jurhum, bahasa Hawazun, bahasa Qudha'ah dan bahasa Thayyi ${ }^{22}$.

Ketika dirampingkan menjadi satu bahasa, demikian pula pluralitas makna bahasa wahyu yang semula terdapat dalam tujuh bahasa sesuai dengan tujuh budaya kabilah, terpangkas dan cakupan wacana yang diwujudkan ke dalam teks tulisan seperti Mushaf Utsmani, akhirnya menjadi terbatas sebatas satu realitas budaya masyarakat Arab Quraisy. Sedangkan Khalifah Utsman telah menghilangkan dan menyensor bahkan memusnahkan korpus kitab-kitab individu, seperti milik Ibnu Mas'ud dan Siti Hafsah. Ini menunjukkan yang jelas, bahwa implikasi pada pemusatan pembacaan hanya pada Mushaf Utsmani. Dengan penyempitan makna wahyu Tuhan yang dibungkus dengan bahasa al-Quran sebagai bahasa lisan, kemudian wahyu Tuhan diperkecil lagi dengan bahasa tulisan yang

22 Khalil Abdul Karim, Negara Madinah: Politik Penaklukkan Masyarakat Suku Arab, (Yogyakarta: LKiS, 2005), 343. 
disebut dengan Mushaf. Jika boleh memberi istilah, Mushaf Utsmani ini telah menjadi "penjara" bagi pesan rahasia Tuhan.

Penjara itu, kian samar, ketika bahasa Arab yang digunakan sebagai pembungkus pesan Tuhan, dan kini telah mewujud dalam bentuk Mushaf, dijadikan sumber asasi pencarian pesan Tuhan dan dibaca dengan pendekatan sinkroni yang merujuk pada penuturnya secara obyektif. Akhirnya, subyektifitas atau obyektifitas menjadi problem mendasar dalam pencarian pesan Tuhan. Dua hal ini bukan sekedar pilihan-pilihan sederhana, tapi mengandung jebakan. Memilih berpikir obyektif, walaupun enak di dengar, dimungkinkan juga sebagai sebuah jebakan yang dibuat oleh penganut budaya dan ideologi tertentu dengan berjalan dibalik asumsi epistemologi. Demikian pula memilih yang kedua. Ketika memilih berpikir yang obyektif, berarti yang akan dicari adalah makna asli sebuah bahasa, sebaliknya memilih berpikir subyektif, juga akan bakal diklaim mengesampingkan pesan Tuhan.

\section{E. Simpulan}

Bahasa Tuhan adalah bahasa yang abstrak diluar jangkauan akal manusia sedangkan al-Quran merupakan bahan kajian teks yang berntuk tulisan untuk memberikan makna baru akan realitas yang melingkupnya. Sementara Mushaf, merupakan reduksi makna terhadap wahyu yang berbentuk bahasa lisan yaitu bahasa al-Quran. Para peminat tentang kebahasaan yang dikembangan oleh pakar strukturalis untuk menemukan makna yang obyektif dan rasional sesuai dengan ruang dan waktu. Salah satu model pendekatan yang digunakan didalam memahami kalam Tuhan dengan analisis linguistik dengan pendekatan parole dan langue, sinkroni dan diakroni serta penanda dan petanda. Perampingan unsur-unsur linguistik tersebut sangat signifikan didalam sistem bahasa yang berlaku.

Sedangkan bahasa Tuhan masuk pada wilayah parole yang tidak bisa ilmiahkan, karena bahasa parole adalah wahyu Tuhan yang tidak di intervensi oleh sisitem bahasa manusia. Berarti kedudukannya, menempati bebas dan tidak terikat pada apapun, inilah yang disebut dengan wahyu personal dan rahasia. Sementara al-Quran merupakan bahasa langue yang dokonstruksi oleh masyarakat secara pasif, artinya sistem bahasa tidak perlu mencari asal-usul tentang bahasa itu sendiri, akan tetapi cukup mengkaji sistem bahasa yang berlaku dan menjalin komunikasi yang efektif sesuai dengan aturan dan budaya masyarakat yang bersangkutan. Didalam linguistik yang disebut dengan sinkroni 
bukan diakroni. Maka didalam linguistik parole dan langue harus berposisi pada ruang yang beda.

\section{DAFTAR PUSTAKA}

Abdul Karim, Khalil, Negara Madinah: Politik Penaklukkan Masyarakat Suku Arab, Yogyakarta: LKiS, 2005.

Abu Zaid, Nasr Hamid. Tekstualitas al-Quran, Kritik Terhadap Ulumul Quran (Terj), Yogyakarta: LKiS, 2001.

Ahimsa Putra, Sri, Strukturalisme Levi Strauss: Mitos Dan Karya Sastra, Yogyakarta: Galang Press, 2001.

Esack, Farid, Samudera al-Quran (Terj), Yogyakarta: Diva Press, 2007.

Hanafi, Hasan. Hermeneutika al-Quran, (Terj), Yogyakarta: Nawesea, 2009. Metode Tafsir Dan Kemaslahatan Umat, (Terj), Yogyakarta: Nawesea, 2007.

Izutsu, Toshihiko. Relasi Tuhan Dan Manusia; Pendekatan Semantik Terhadap al-Quran, (Terj), Yogyakarta: Tiara Wacana, 1997.

K. Bartens, Fisafat Barat Kontemporer Prancis (Terj), Jakarta: Gramedia Pustaka Utama, 2001.

Khaldun, Ibnu. Muqaddimah, (Terj), Jakarta: Pustaka Firdaus, 1986.

Kurniawan, Semiologi Roland Barthes, Magelang: Indonesiatera, 2001.

Mubarok, Ahmad Zaki. Pendekatan Strukturalisme Linguistik Dalam Tafsir al-Quran Kontemporer, Yogyakarta: elSAQ Press, 2007.

Ricoeur, Paul. Filsafat Wacana; Membelah Makna Dalam Anatomi Bahasa, (Terj), Yogyakarta: IRCiSoD, 2002.

Ruslani, Masyarakat Kitab dan dialog antara Agama, Yogyakarta: Bentang Budaya, 2000.

Syafi'I, Imam: Moderatisme, Eklektisisme, Arabisme, Yogyakarta: LKiS, 1997.

Wijaya, Aksin. Arah Baru Studi Ulum al-Quran; Memburu Pesan Tuhan Di Balik Fenomena Budaya, Yogyakarta: Pustaka Pelajar, 2009. Menggugat Otentisitas Wahyu Tuhan; Kritik Atas Nalar Tafsir Gender, Yogyakarta: Safiria Insania Press, 2004. 
"Diskursus Bahasa Tuhan"

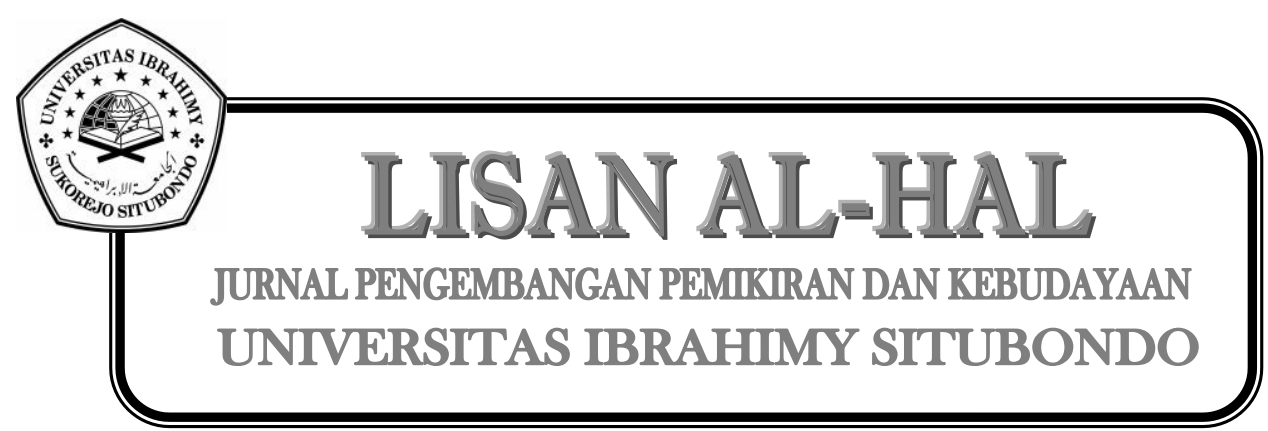

384 JURNAL LISAN AL-HAL 